\title{
Research Paper \\ Comparison of the Effectiveness of Mindfulness Training and Attention Bias Modification in Reducing Social Anxiety of the Female Students
}

\author{
Sepideh Salmani Cholabi ${ }^{* 1}$, Mansour Hakim Javadi ${ }^{2}$, Reza Soltani Shal ${ }^{3}$
}

1. M.A. Student of General Psychology, Faculty of Literature and Humanities, University of Guilan, Rasht, Iran 2. Associate Professor, Department of Psychology, Faculty of Literature and Humanities, University of Guilan, Rasht, Iran 3. Assistant Professor, Department of Psychology, Faculty of Literature and Humanities, University of Guilan, Rasht, Iran

Citation: Salmani Cholabi S, Hakim Javadi M, Soltani Shal R. Comparison of the effectiveness of mindfulness training and attention bias modification in reducing social anxiety of the female students. Quarterly Journal of Child Mental Health. 2020; 7(1): 32-43.

\section{http://dx.doi.org/10.29252/jcmh.7.1.4}

\section{A R T I C L E I N F O}

Keywords:
Mindfulness training,
attention bias
modification,
social anxiety

Received: 15 May 2018 Accepted: 6 Sep 2018 Available: 16 May 2020

\section{A B S T R A C T}

Background and Purpose: Social anxiety disorder is one of the most common disorders of late childhood and adolescence, associated with impaired daily functioning and a significant reduction in quality of life. Given that adolescence is a sensitive period in personality formation, finding effective treatment for social anxiety disorder that reduces the severity and depth of its symptoms, has considerable importance. This study aimed to compare the effectiveness of mindfulness training based stress reduction (MBSR) and attention bias modification training (ABMT) for reducing social anxiety disorder.

Method: The research method was semi-experimental with pre-test- post-test design with a control group. The statistical population of the study consisted of all students of 13 to 15 year old in Astaneh Ashrafieh city in the academic year of 2017-2018. At first, using a convenience sampling method, two schools were selected among the schools of that area. After that, 45 students who had a high social anxiety score selected and assigned in three equal groups (two experimental groups and one control group). For one experimental group, MBSR was performed in eight 60- minute sessions, and for the second experimental group, ABMT was performed in four 30- minute sessions. The control group also did not receive any intervention. The research instrument was Liebowitz Social Anxiety Scale for Children and Adolescents (Masia-Warner, Storch, Pincus, Klein, Heimberg \& Liebowitz, 2003) and data were analyzed by one-way covariance analysis method

Results: The results showed that MBSR and ABMT was effective in reducing social anxiety disorder scores $(\mathrm{p}<0.05, \mathrm{~F}=26.32)$. Also, based on the results of the post hoc test, MBSR (MD=49.95) was significantly more effective than ABMT $(\mathrm{MD}=63.02)$ in reducing social anxiety in female students $(\mathrm{P}<0.05)$.

Conclusion: The results showed that both methods used in this study were effective in reducing social anxiety, but MBSR due to group performance as well as continuous homework compared to the ABMT, has been more effective.

\footnotetext{
* Corresponding author: Sepideh Salmani Cholabi, M.A. Student of General Psychology, Faculty of Literature and Humanities, University of Guilan, Rasht, Iran.

E-mail addresses: Se.salmani@yahoo.com
} 


\section{مقايسه اثربخشى آموزش ذهن آكاهى و تعديل سو كيرى توجه در كاهش اضطراب اجتماعى دانش آموزان دختر

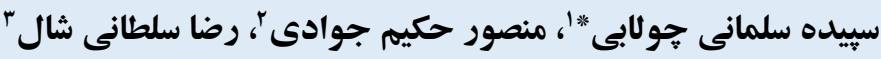

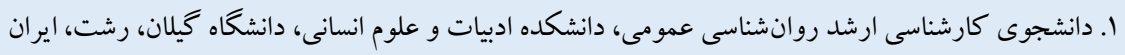

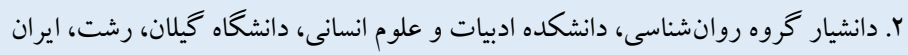

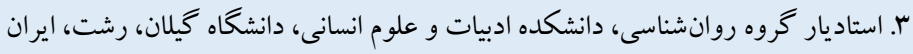

جكيده

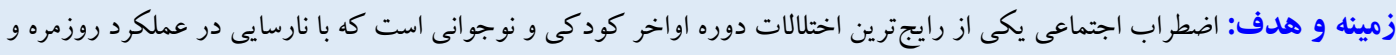

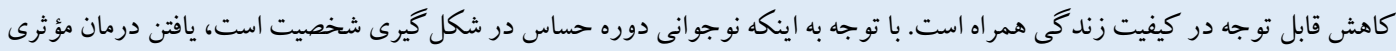

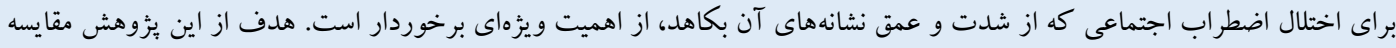

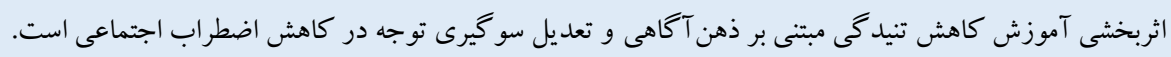

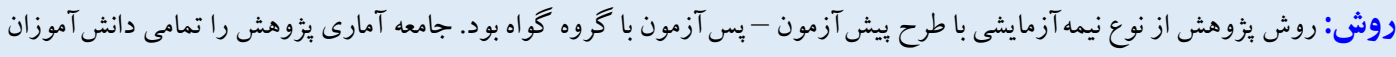

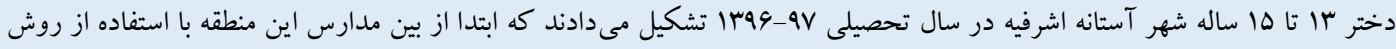

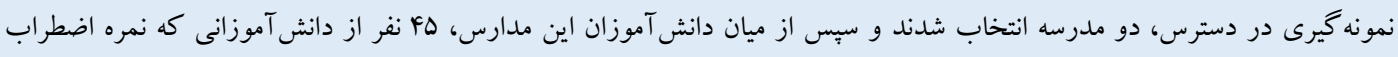

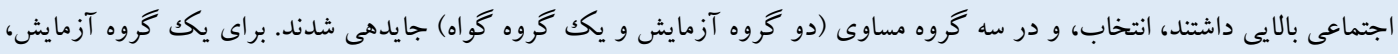

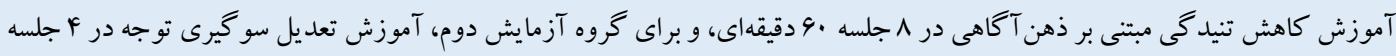

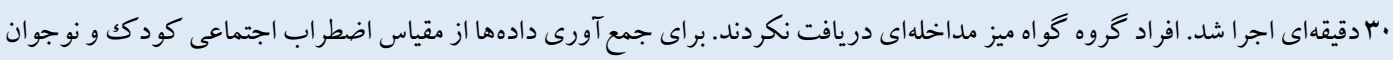

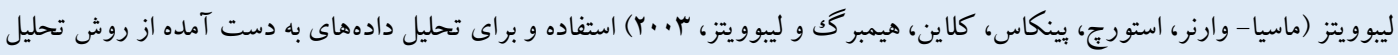
كوواريانس تككمتغيرى يكر اهه استفاده شد.

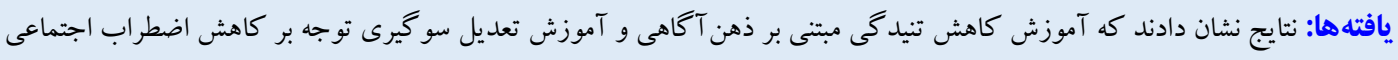

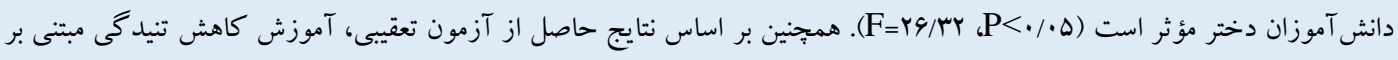

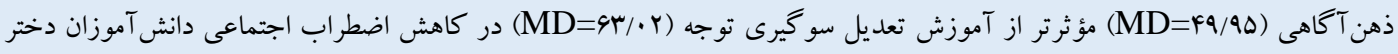

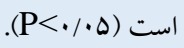

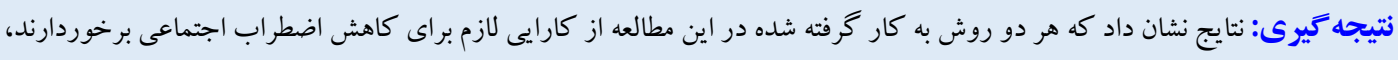

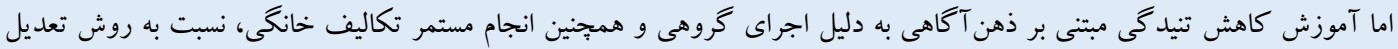

$$
\text { سو گيرى توجه، مؤثرتر بوده است. }
$$

مشخصات مقاله

كليدوازهها: آموزش ذهن Tكاهى،

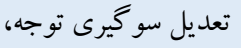

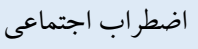

\section{مقاله بثز}


اسـت كـه در اين موارد، مكانيزم مرتبط بر ذهن آكاهى مى تواند به طور

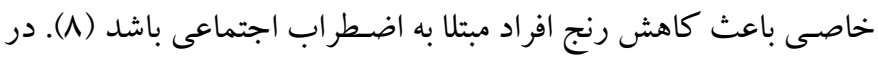

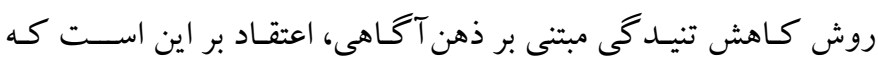

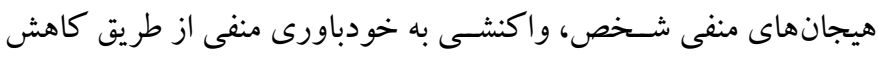
در فعاليت مغزى مرتبط با واكنشهاى هيجانى و افزايش شبكههاى مغزى

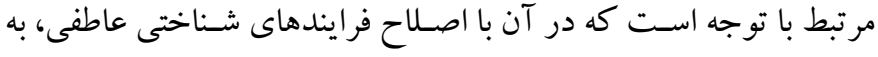

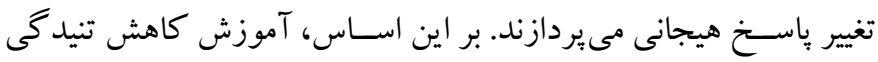

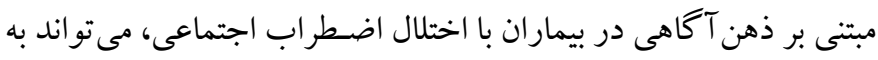

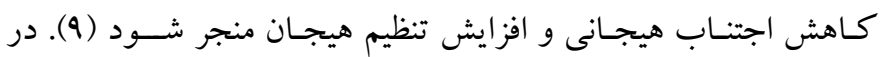

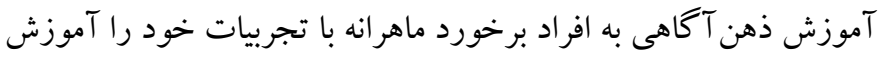

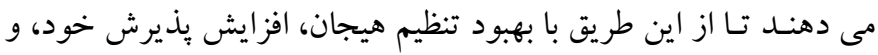

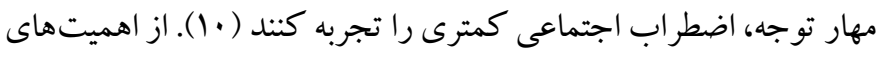

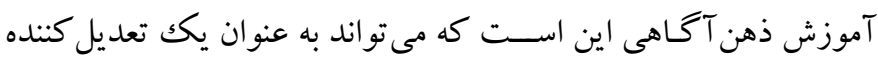

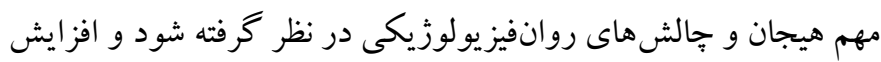

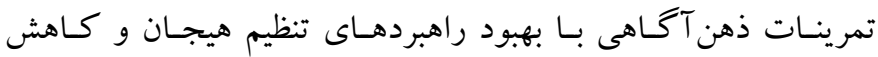
آسـيـبـيـذيرى نســــت بـهـ اختلالات هيجانى همر اه اســت و در نتيجه

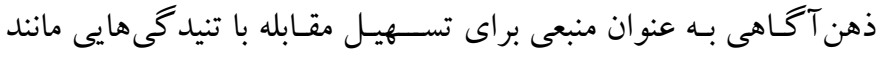

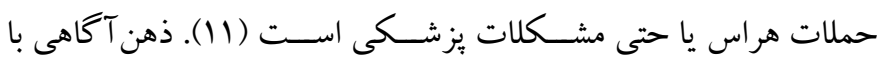

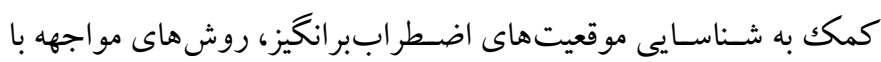

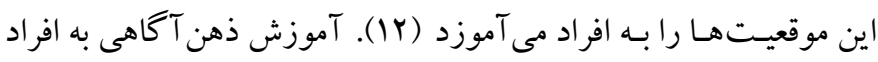
مى آموزد كه با مواجهه و انعطافيذيرى در موقعيتها به جاى اجتناب از

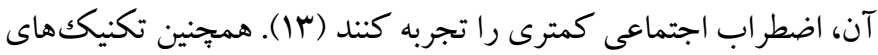

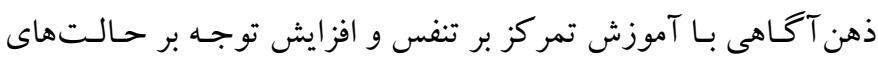

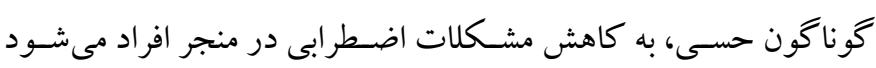

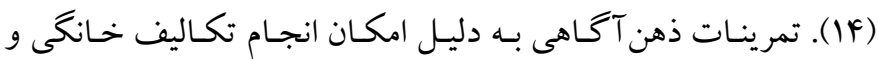
راهبردهاى ســريع و مؤثر در خودمهار گرى مى توانند روش مناسـبى در

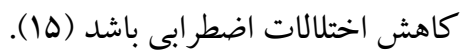

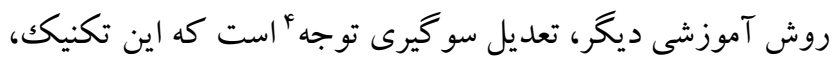
ابزارى جهـت بررسـى نقش فراينـدهـاى بردازش اطلاعات در اختلالات

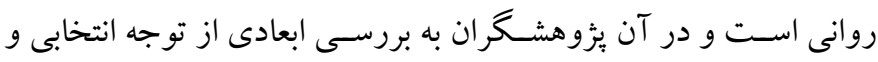

مقلمهه

اختلال اضطراب اجتماعى' ترسى فراگير از ظاهر شدن در ميان ديخران

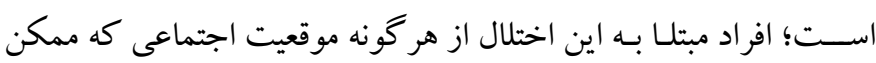

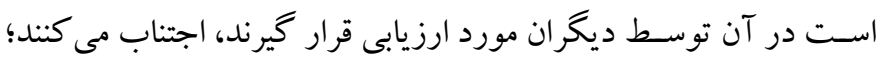

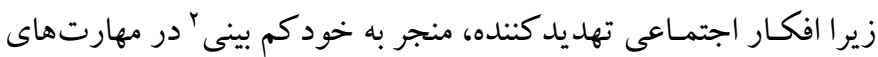

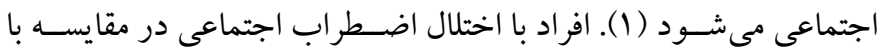
افراد فاقد اضطراب، تا حد بيشترى جنبه هاى مهمى از زندكى را بى ارزش

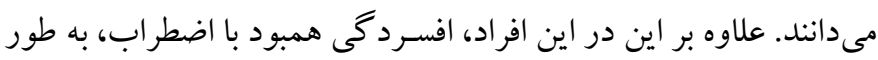

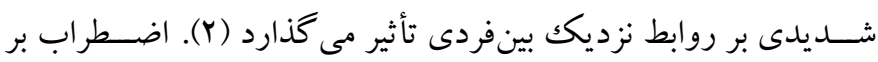

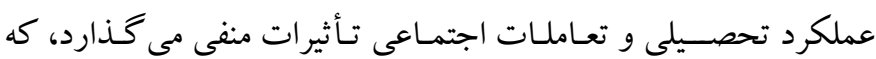

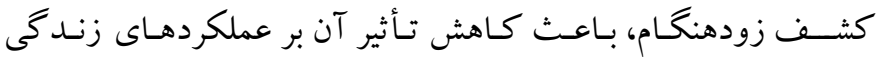

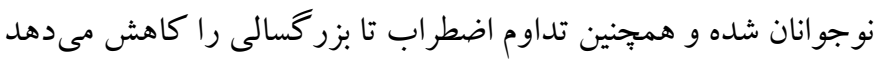

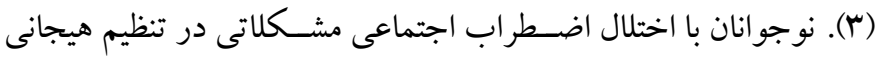
دارند و بيشـتر اين افر اد از راهبردهاى سـازشنايافته تنظيم هيجان استفاده كرده و راهبردهـاى جـديـــ تنظيم هيجـان را، كمتر بـه كار مىبرند (F). اختلالات اضـطرابى در نوجوانى با نقص در عملكرد و كاهش قابل توجه

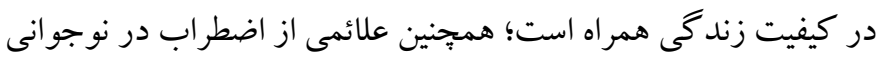

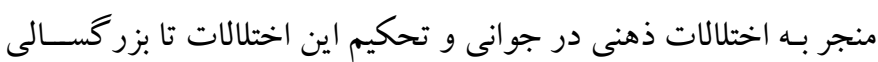

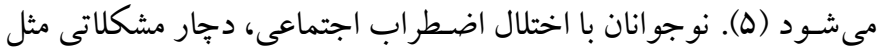
كاهش مهارت هاى اجتماعى، مشكلات بينفردى و سطوح بالاى تنهايى، امتناع از مدرسـه رفتن، كاهش بذيرش اجتماعى، و صـلاحيت اجتماعى

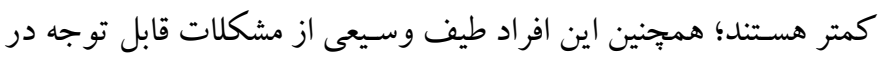

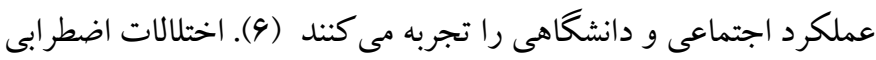

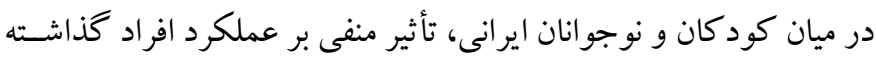

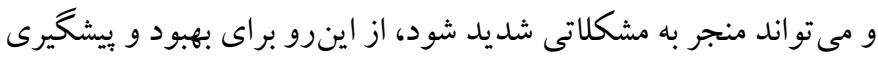

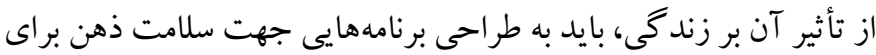
كود كان و نوجو انان برداخت (V)

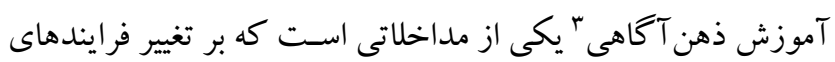

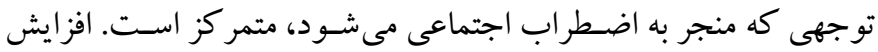
توجه متمر كز بر نشانهاى بدنى، مكانيزم مركزى حفظ اضطراب در افراد

1. Social anxiety disorder

2. Inferiority complex 


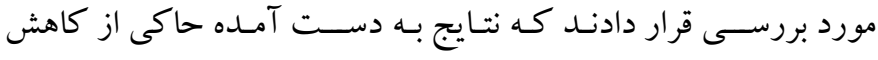

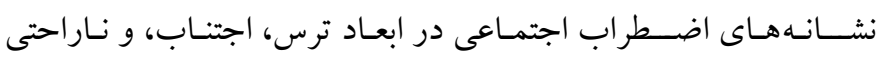

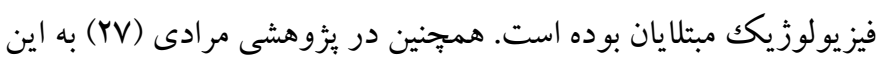
نتيجه دست يافت كه درمان ذهن آكاهى باعث كاهش اضطراب اجتماعى دورئي مادران داراى دانش آموز كم توان ذهنى مى شودم.

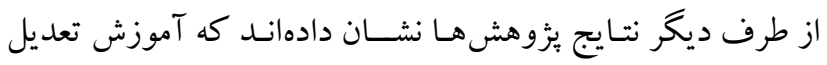

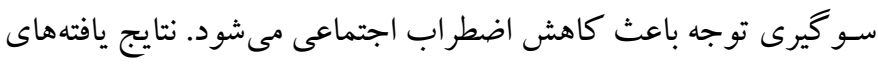

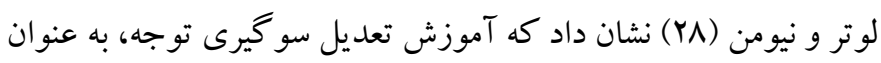

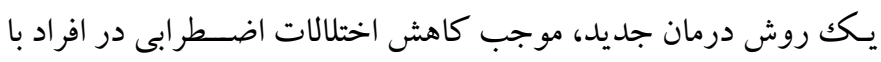

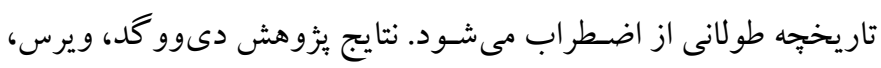

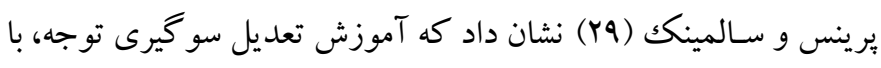

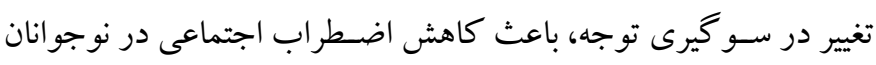

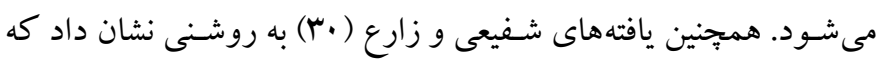

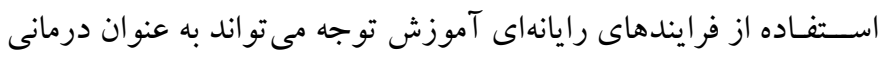
موثر در كـاهش اضـطر اب اجتمـاعى مورد اســفـاده قرار كيرد. نتـايج

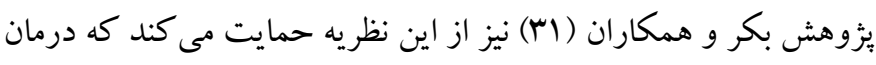

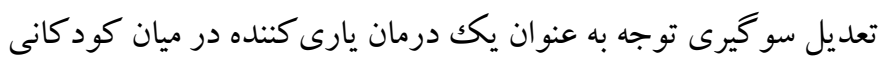

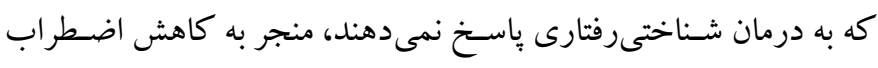

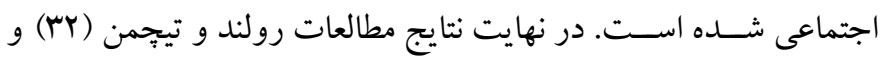

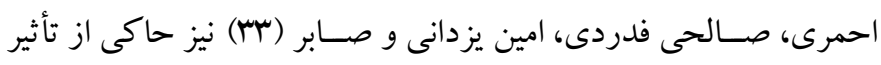

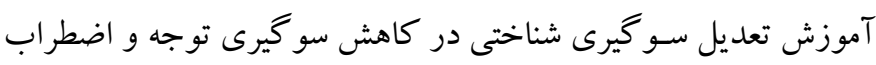

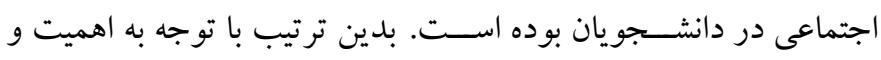

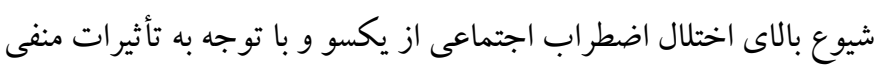

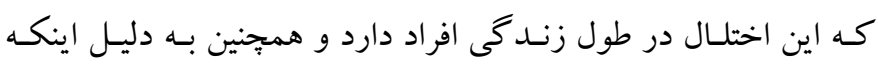

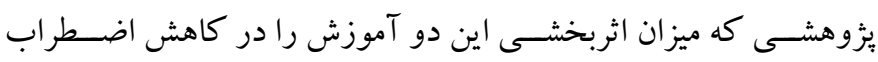

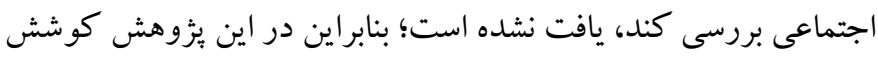

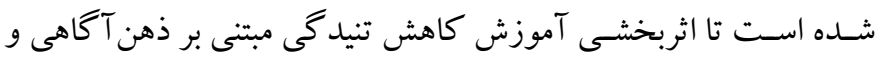

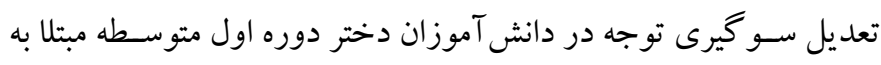
اضطراب اجتماعى، بررسى و با هم مقايسه شود.
يردازش اطلاعات مى يردازند كه در واكنش هاى هيجانى ناخوشايند نقش دارند كه در نتيجه به تغيير توجه از رويدادهاى تهديد كننده به رويدادهاى

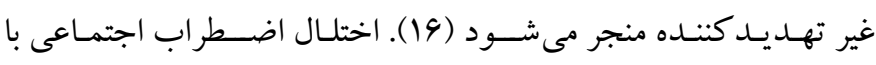

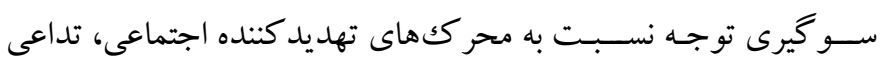

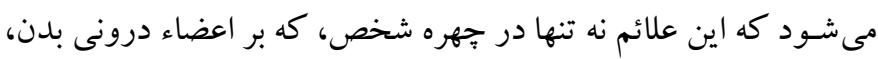

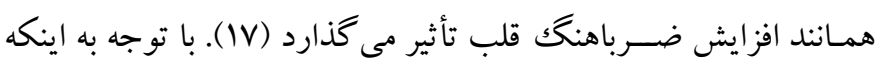

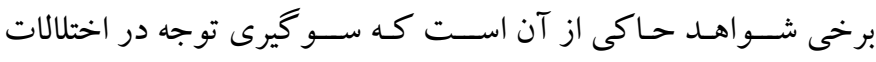

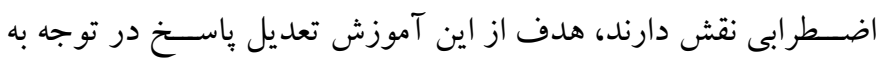

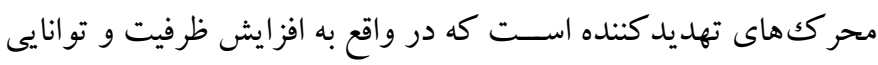
در مقابله با موقعيت تهديد كننده و كاهش سو گيرى توجه به تهديد، منجر

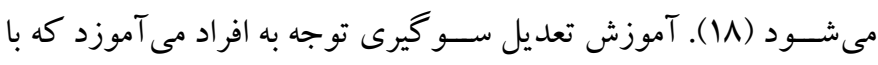

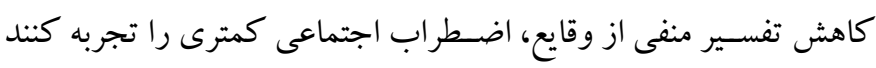

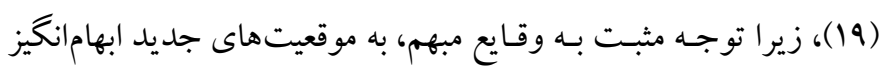

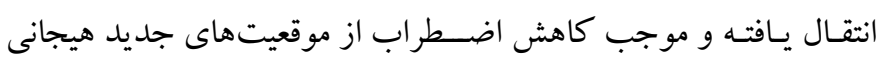

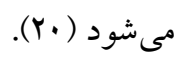

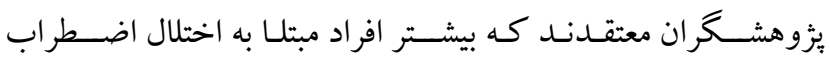

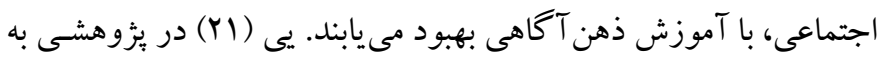

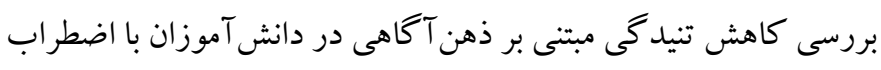

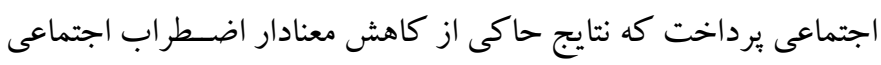

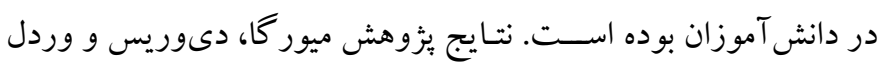

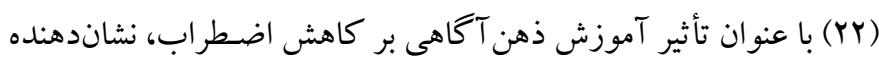

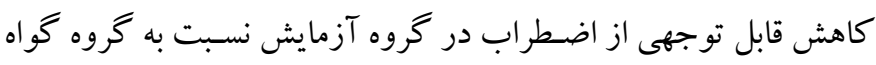

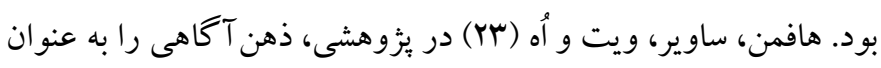

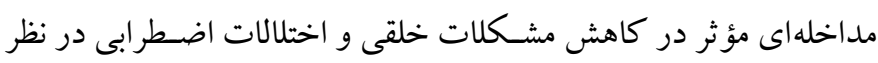

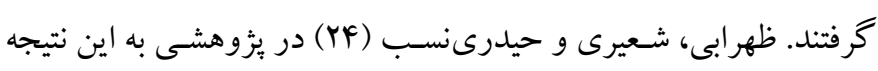

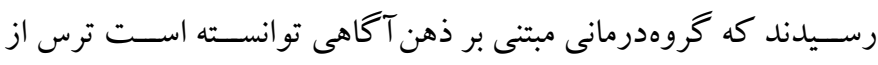

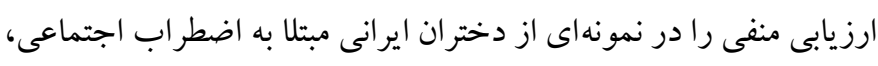

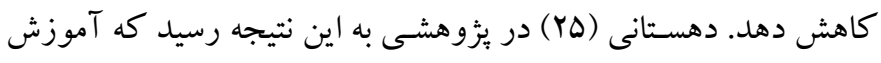

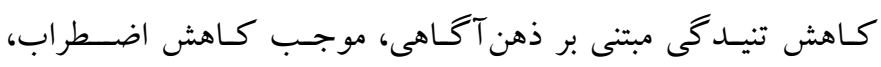

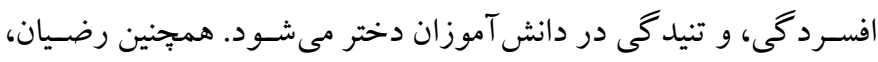

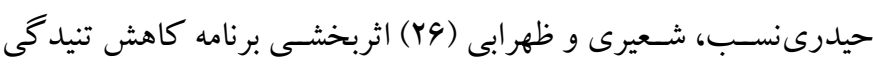

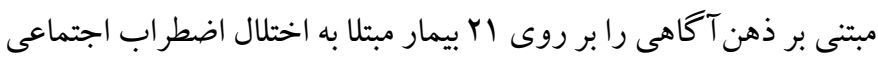


سؤ الات بر روى يكك مقياس \& درجهاى ليكرت باسخ مىدهد. هر عبارت

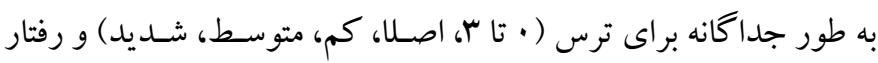

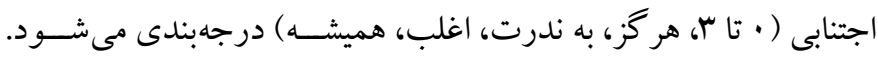

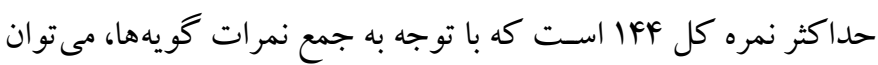

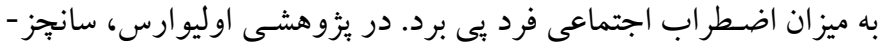

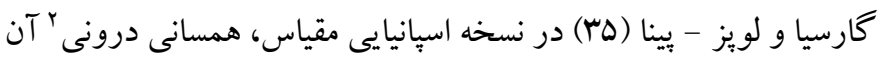

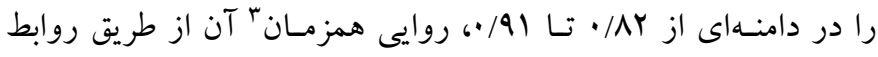

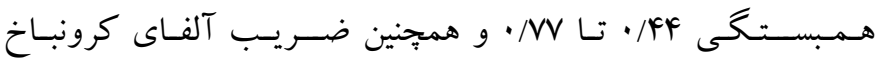

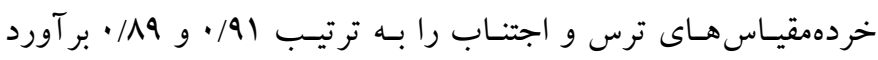

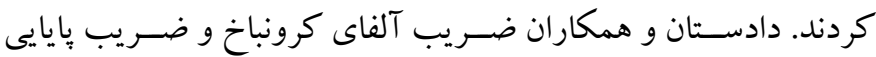

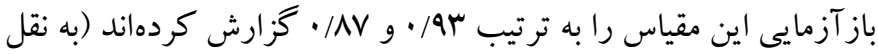

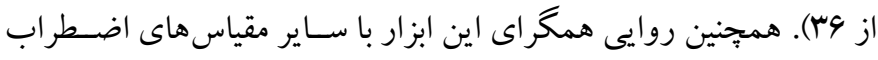

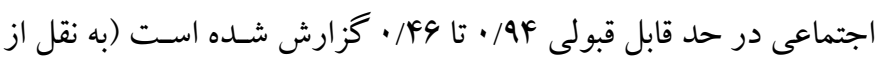

ج) برنامه مداخلهاى: در اين مطالعه دو نوع برنامه مداخلهاى به شرح زير

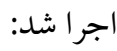

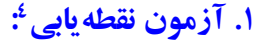

آزمايه نقطه يابى با اسـتفاده از نرمافزار سـويرلب سـاخته شــده و از طريق

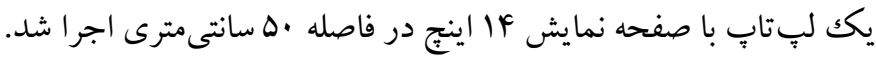

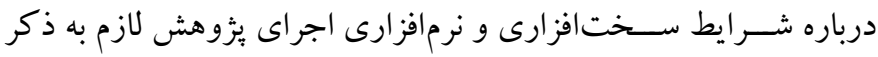

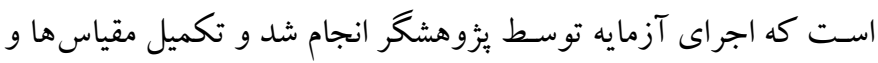

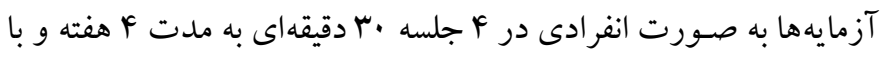

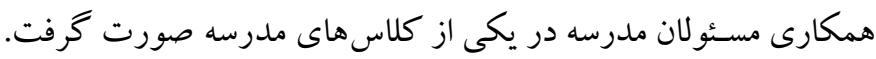

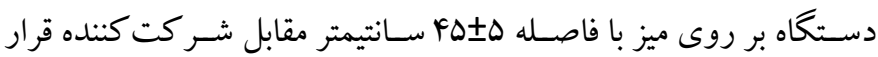

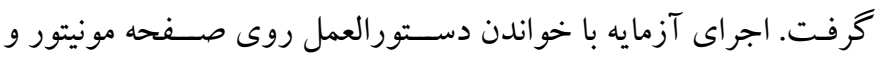

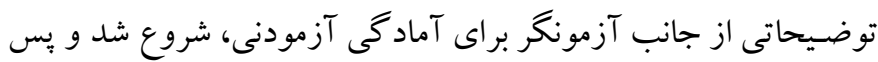

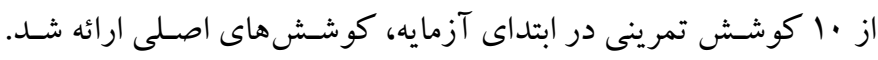

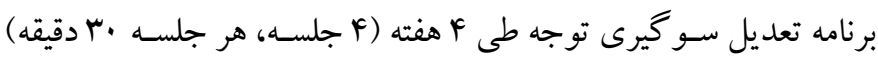

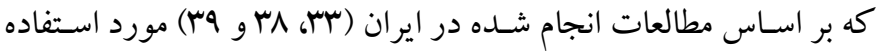

الف) طرح هزوهش و شـــ كت كنند كان: روش يزٔوهش حاضر از نوع

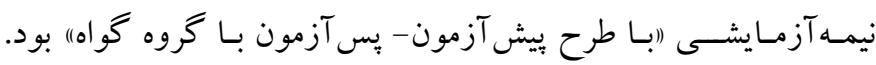

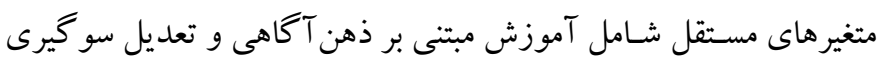

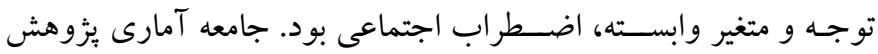
حاضـر را، دانش آموزان دختر دوره اول متوسطه ( سا تا ها سـال) شهـر

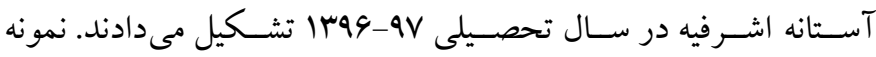

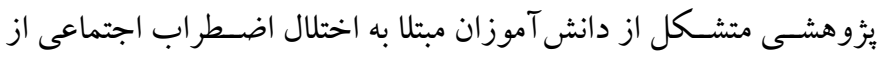

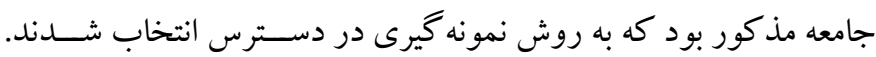

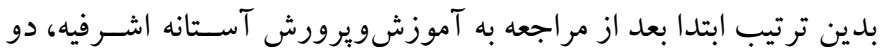

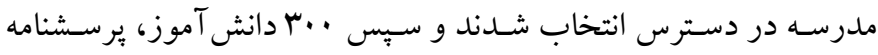

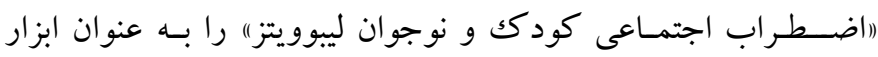

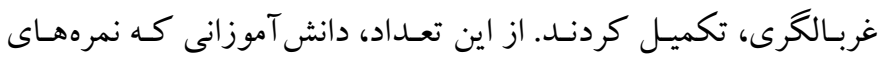

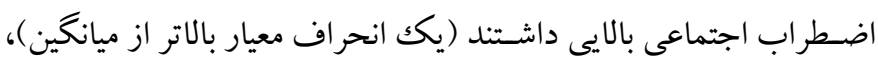

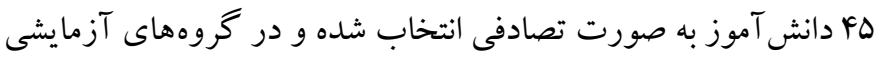

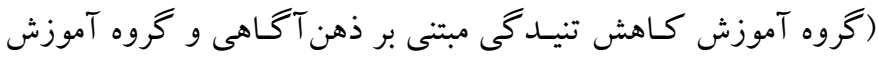

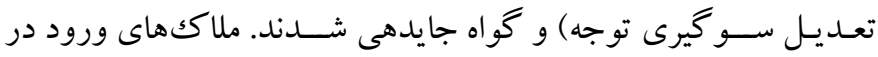

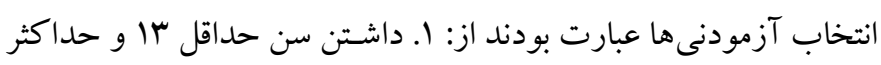

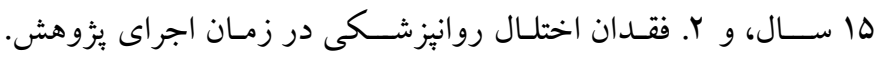
ملـاككهـاى خروج عبـارت بودنـد از: ا. مبتلا بودن به هر نوع بيمارى كه

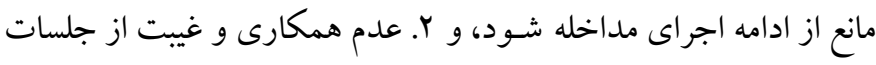

مداخله.

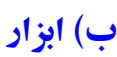

يرسشـنامه اضطراب /جتماعى كودكان و نوجوانان ليبوويتز إ: اين مقياس را ماسـيا- وارنر و همكاران (FF) بر اســاس مقياس اضـطر اب اجتماعى

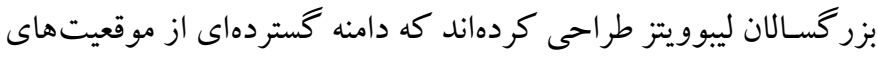

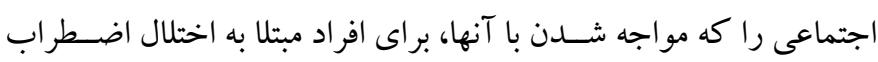

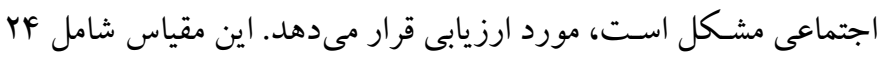

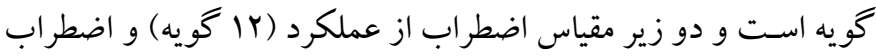

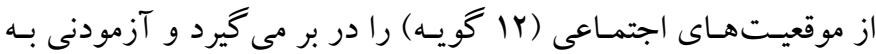

1. Liebowitz

2. Internal consistency 
جهره تهلديدآميز باشـد، اجتناب توجه نسبت به تصوير جهره منفى مطرح

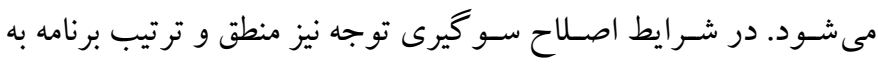

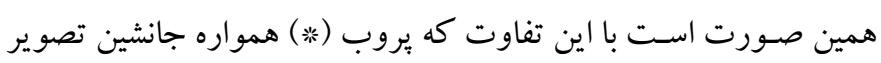

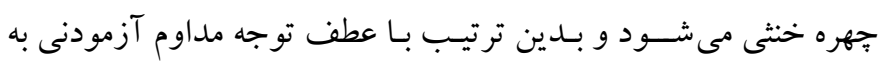

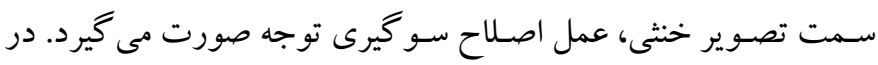

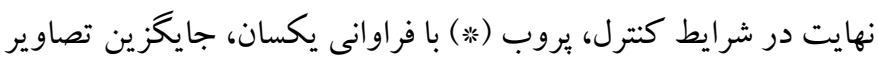

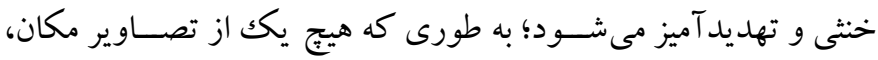

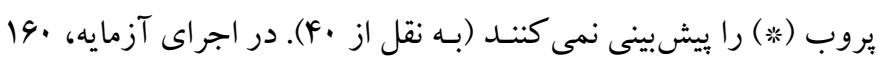

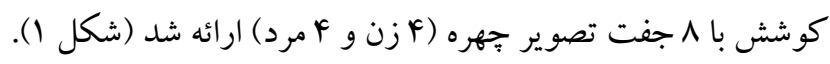

\section{شكل 1: نمونهاى از اسلايدهاى ارائه شده در آزمون نقطهيابى}

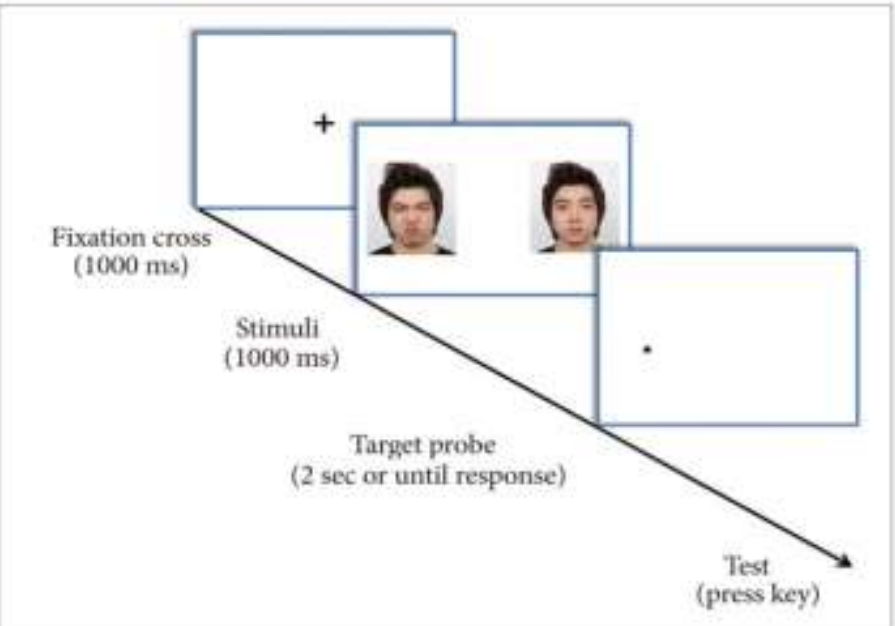

r. آموزش كـاهش تنيـدكى مبتنى بر ذهن آكـاهى ': آموزش كـاهش

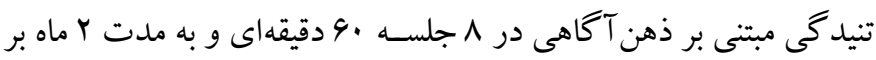

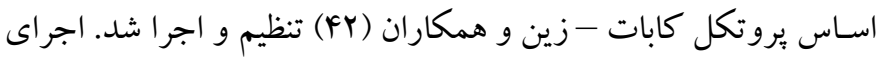

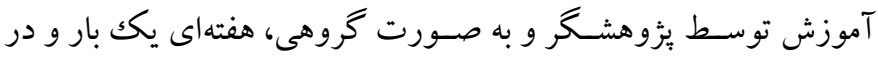

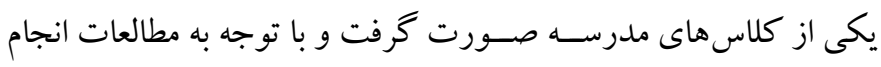

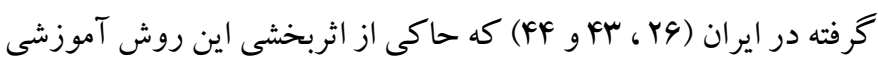
بر اضطراب است، مورد استفاده قرار گرفته است.
قرار گر فته اسـت. محتواى جلسـات، يكسـان و هدف آنها، تغيير توجه از جهرههاى تهلديد كننده به جهرههاى خنثى است.

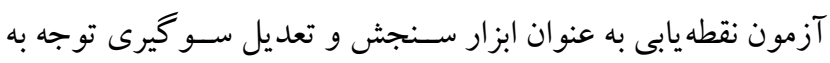

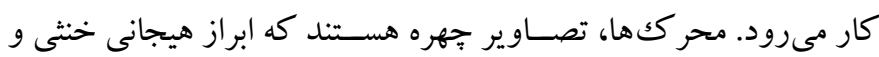
تهلديد كننده رانشـان مىدهند. تصـاوير جهره از آنجا مورد اسـتفاده قرار كرفت كه نسبت به لغات، محر ككهاى اختصاصى ترى هستند (به نقل از

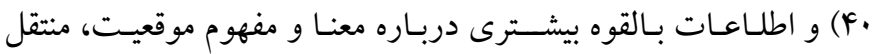
مى كنند. از طرفى، ارزيابى هاى اجتماعى اغلب به صورت غير كلامى ابراز

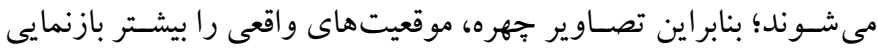

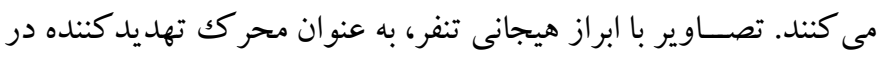

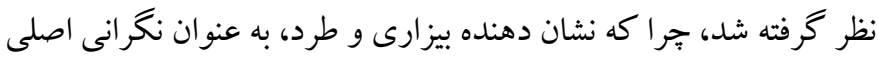

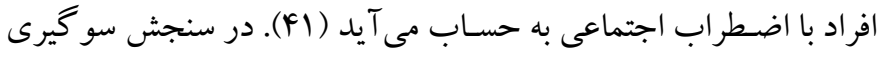
توجه، كوششهاى آزمايه به اين ترتيب اجرا مىشود كه نقطه تثبيت (+)

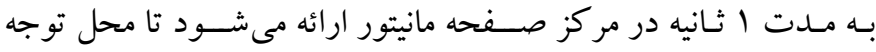

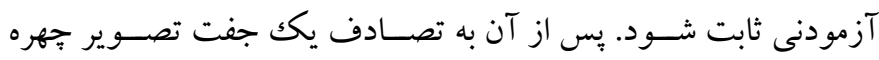

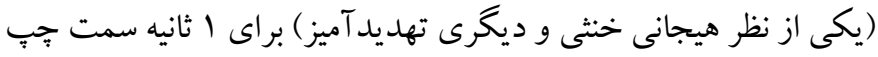

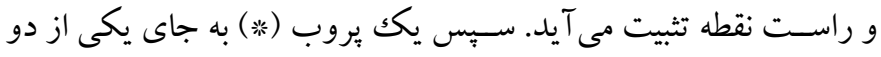

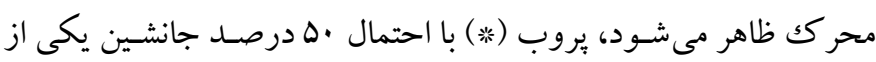

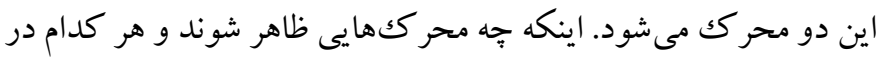

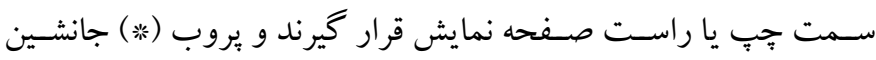

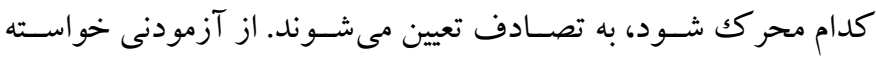

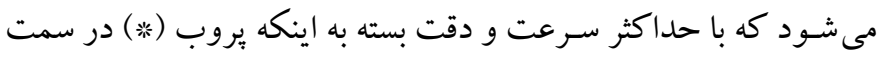

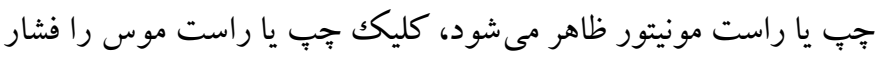
دهد. يروب (*) تا پاسخدهى وى در صفحه باقى مى ماند. كوشش بعدى

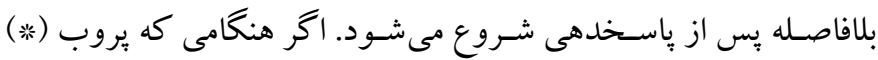
جانشين تصوير جهره تهديد آميز مى شود، زمان واكنش آزمودنى كمتر از

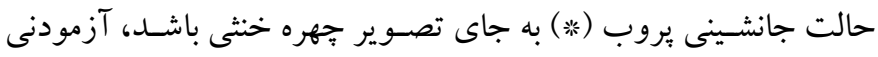
سو گيرى توجه نسبت به محر ككهاى منفى مرتبط با تهليد نشان مى دهد.

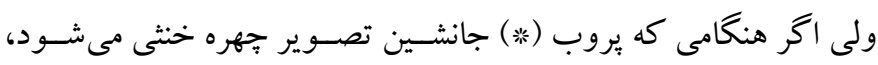

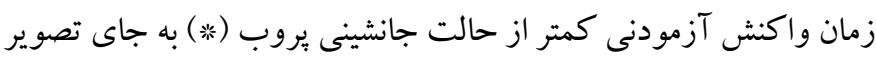




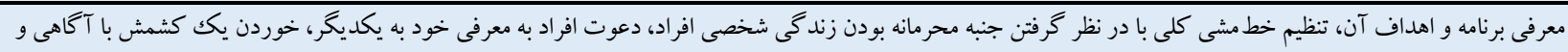

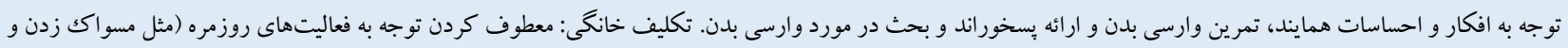

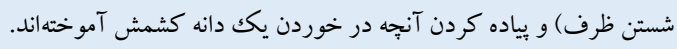

تمرين وارسى بدن و بازنخرى تمرين، شرح عوامل ايجادكننده فشار روانى و اضطراب، تمرين انجام تنفس با حضور ذهن. بازنخرى تكاليف خانخى. تكاليف خانخى: روزانه ده دقيقه

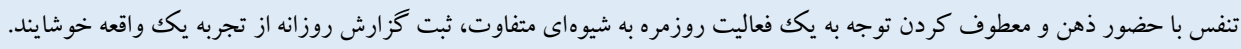

جلسه دوم

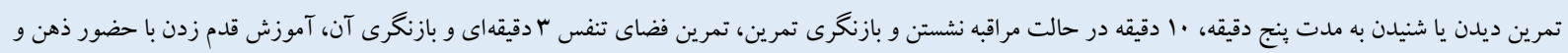

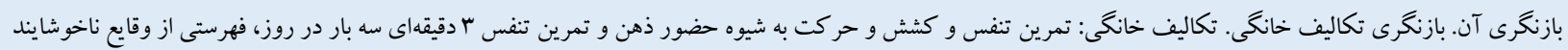
جلسه سوم روزانه

تمرين ينج دقيقهاى ديدن يا شنيدن، ها دقيقه مراقبه آكاهى از تنفس، صدا و افكار و بازنخرى تمرين، انجام فضاى تنفس سه دقيقهاى، بازنخرى تكاليف خانگى. تكاليف خانگى: مراقبه

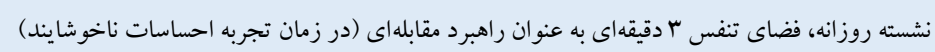

جلسه جهارم

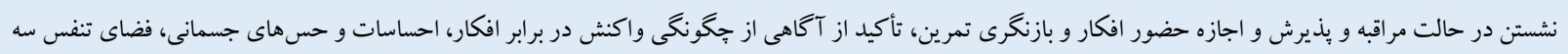

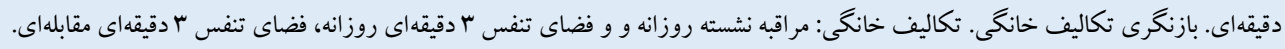

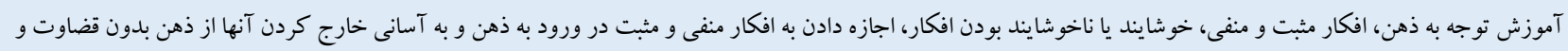

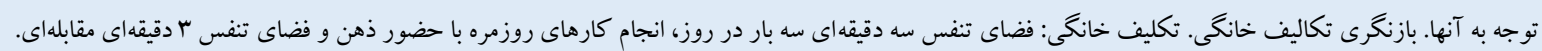

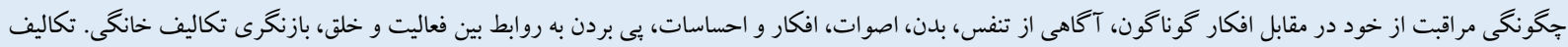

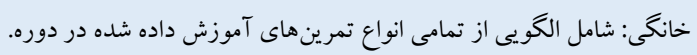

كرفته و براى توليد مستندات علمى استفاده شده، و كاملا محرمانه باقى

مى ماند.

\section{مافته}

ميانگين و انحراف اســاندارد نمرات يِيش آزمون- يس آزمون متغيرهاى يزٔوهش دو گروه آزمايش ( ا. ذهن آكاهى، r. تعديل سو گيرى توجه) و كواه در جدول Y ارائه شـده اسـت. همجِنين در اين جدول نتايج آزمون شــاييرو -ويلـك براى بررسـى نرمـال بودن توزيع متغيرهـا در كروههــا

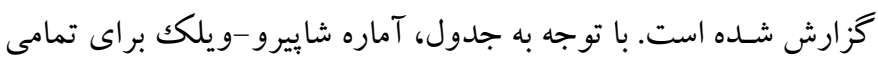
متغيرهـا معنى دار نيســت، بنـابراين مى توان نتيجـه كرفت كه توزيع اين متغير ها نرمال است.
د) روش اجرا: به منظور اجراى يثوهش حاضر، ابتدا مجوزهاى للزم جهت اجراى يزوهش، از آموزشو يرورش كرفته شد و با مراجعه به مدارس معرفى شده توسط آموزشو يرورش و تكميل يرسشنامه توسط دانش آموزان، نمونه مورد نظر انتخاب و نمونهها به صورت تصادفى در گروههاى آموزش ذهن آكاهى (1 جلسه ·4 دقيقهاى)، تعديل سو گيرى توجه (F جلسه ·r دقيقهاى)، و گروه گواه (بدون آموزش) جايدهى شدند. همجينين جهت رعايت ملاحظات اخلاقى، در ابتداى انجام يثزوهش، اهداف اين مطالعه براى دانش آموزان بيان شد و رضايت كامل آنها براى شركت در بزؤهش جلب شد و هيج دانش آموزى مجبور به تكميل برسشنامه و شر كت در جلسات نبود. همجنين به افراد شركت كننده اطمينان داده شد كه اطلاعات حاصل از اين بزوهش به صورت گروهى مورد تحليل قرار 
جدول r: شاخصهاى توصيفى نمرات ييشآزمون-يس آزمون در دو كروه آزمايش و كواه (تعداد: 0ع نفر )

\begin{tabular}{|c|c|c|c|c|c|c|}
\hline $\mathbf{P}$ & شاييرو-ويلك & انحراف استاندارد & ميانكين & كروه & وضعيت & متغير \\
\hline.$/ 91$ &.$/ 9 V$ & $V / 90$ & $V F / F V$ & آموزش ذهن آكاهى & & \\
\hline$\cdot / \cdot \Lambda$ & $\cdot / A \mid$ & $9 / 4 \wedge$ & $v \Delta / q r$ & آموزش تعديل سو گيرى توجه & ي ييش آزمون & \\
\hline .1 .4 & $\cdot / M$ & $V / \Delta F$ & $V r / F$. & كواه & & اضطر اب اجتماعى \\
\hline .1 & $\cdot / 9$. & $9 / \mathrm{TV}$ & $\uparrow q / 9 \Delta$ & آموزش ذهن آكاهى & & \\
\hline.$/ 11$ & $\cdot / 9$ & $11 / \Delta 1$ & $9 \% / . r$ & آموزش تعديل سو گيرى توجه & 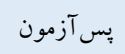 & \\
\hline$\cdot \cdot v$ & $\cdot / A 1$ & $1 . / 14$ & $V F / 10$ & كواه & & \\
\hline
\end{tabular}

ركرسـيون يشـتيبانى مى كنند. نتايج آزمون لوين براى بررسـى همخنى

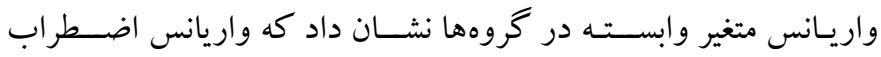

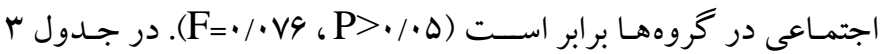

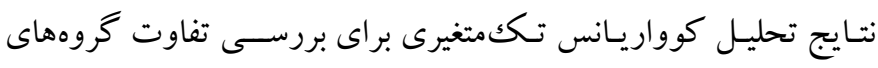

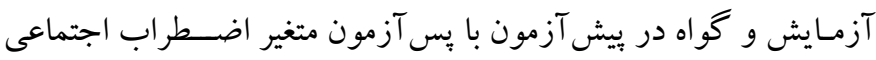
كز ارش شده است.
جهت بررسـى مقايسـه اثربخشى روشهاى آموزشسى بر اضـطراب

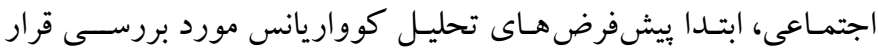

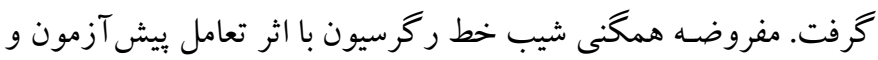

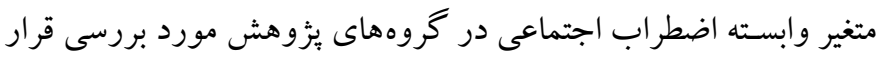

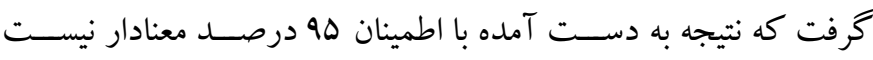

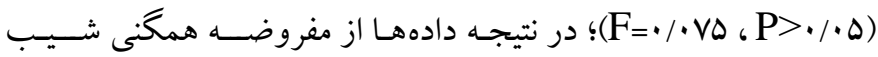

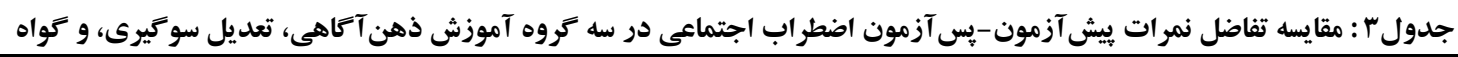

\begin{tabular}{|c|c|c|c|c|c|c|}
\hline اندازه اثر & $\mathbf{p}$ & T Fاره F & ميانكين مجذور ات & درجه آزادى & مجموع مجذورات & منابع \\
\hline$\cdot / r \Delta$ & $\cdot / \cdot \cdot 1$ & $1 \pi / 91$ & $\| F T / \cdot r$ & 1 & $\| F Y / \cdot r$ & ييش آزمون \\
\hline \multirow[t]{2}{*}{$\cdot 109$} & $\cdot / \cdots$ & YG/TY & r199/99 & r & rrar/Tr & عضويت گروهى \\
\hline & & & $\Lambda r / F F$ & \&l & MFYI/Pr & خطا \\
\hline
\end{tabular}

بوده اسـت؛ اين بدان معناسـت كه وه درصد تغييرات متغير وابسته توسط

$$
\text { عضويت كروهى تبيين مى شود. }
$$

جهـت بررسـى اين برســش كـه كـدام يكك از روشهاى آموزش سئس ذهن آكاهى و تعديل سو گيرى توجه بر كاهش اضطر اب اجتماعى مؤثرتر است، اثربخشى گروههاى آموزشى اثرات اصلى با اصلاح بونفرونى مورد بررسـى قرار كرفت. در جدول زير اثر اصـلاح بونفرونى روى تفاضــل

$$
\text { ميانخين ها ارائه شده است. }
$$

بـا توجسه بـه نتـايج جـدول آ، آموزش كـاهش تنيـدگى مبتنى بر ذهن آكاهى و آموزش تعديل سـو گيرى توجه، توانســه اسـت به ايجاد تفـاوت معنادار ميانگگين متغير وابســته در مرحله يس آزمون منجر شــود

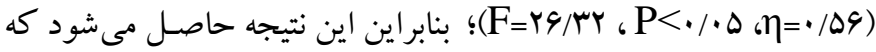

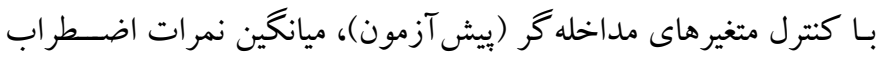
اجتمـاعى دانش آموزان كـاهش يـافته اســت. مقـدار تأثير آموزشهاى كاهش تنيدگى مبتنى بر ذهن آكاهى و تعديل سو گيرى توجه 9ه درصد

\begin{tabular}{|c|c|c|c|c|c|c|}
\hline دامنه بالا & دامنه پإيين & معنادارى & انحراف استاندارد & تفاوت ميانكينها (I-J) & كروهها (J) & (I) \\
\hline$-F / N Y$ & $-r I / F r$ &.$/ \cdot 1$ & $r / \mu F$ & $-\mid r / \cdot V$ & آموزش تعديل سو گيرى توجه & آموزش ذهن آكاهى \\
\hline$-10 / 19$ & -MY/QF &.$/ \cdots$ & $r / \mu F$ & $-Y F / Y$. & كواه & \\
\hline$-Y I / A r$ & F/VY &.$/ \cdot 1$ & $r / r 4$ & $\mid r / \cdot V$ & آموزش ذهن آكاهى & آموزش تعديل سو گيرى توجه \\
\hline$-r / N r$ & $-19 / \Delta r$ & .1 .49 & r/rq & $-11 / 1 \%$ & كواه & \\
\hline
\end{tabular}

جدول ع: تفاوت ميانكينها و دامنه اطمينان تفاوتها به تفكيك تروههاى ثئوهش 
تمر كز بر زمان حال و آكاهى هدفمندانه، به فرد كمك مى كند كه نسبت

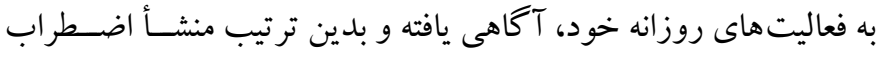

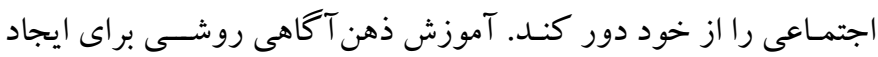

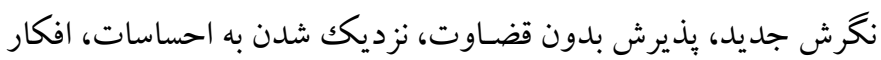
و حس هاى بدنى، براى خلاص شدن از حالات خلقى منفى است (به نقل

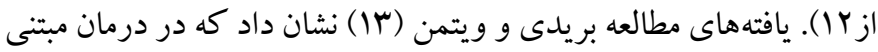

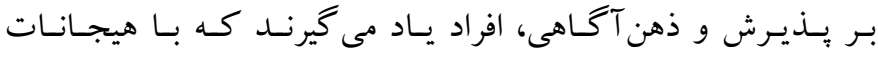

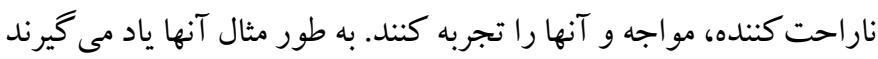

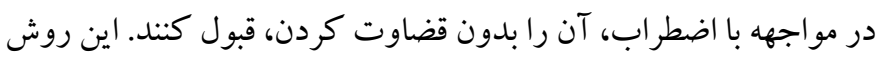

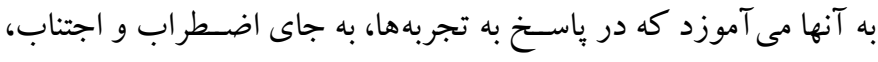

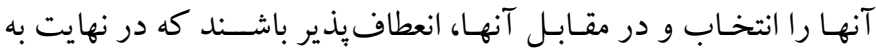
كاهش اختلال اضطر اب اجتماعى منجر مىشود.

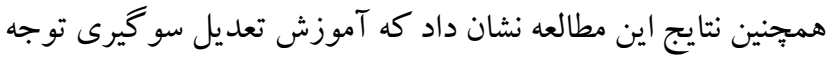

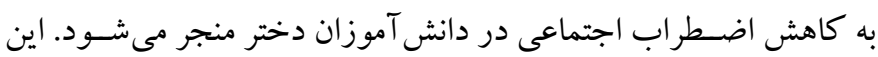

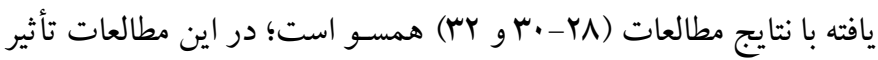
آموزش تعديل سـو گيرى توجه بر كاهش اضطراب اجتماعى تأييد شده

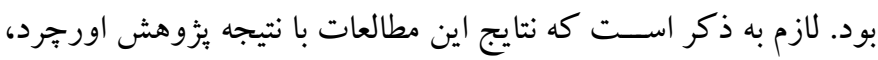

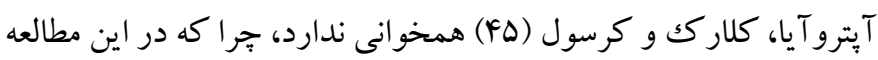

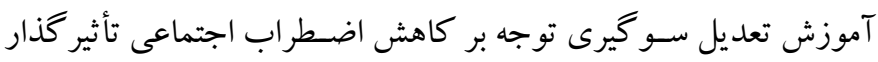

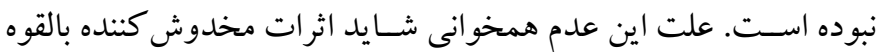

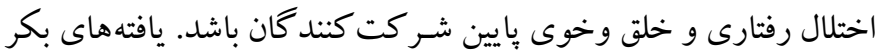

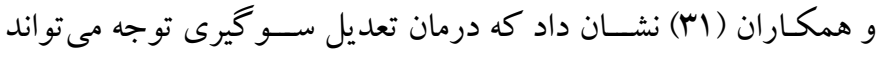
باعث كاهش اضطراب در ميان كود كانى كه به درمان شناختى - رفتارى

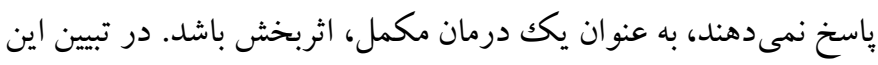

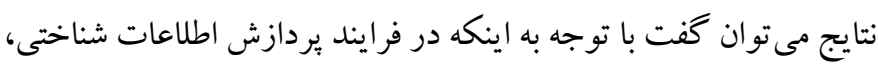

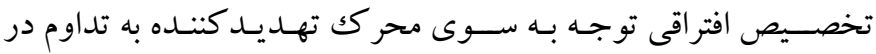
اضطر اب اجتماعى منجر مىشود، در تعديل سو گيرى توجه، با استفاده از

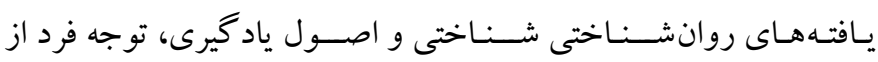
محر ككهاى تهديدزا جدا شـده و به سمت محركك هاى خنثى، سوق داده

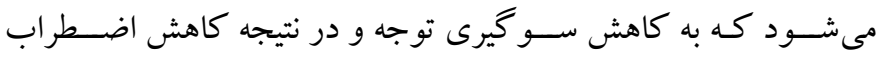

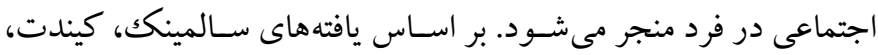

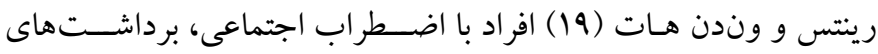

با توجه به جدول فوق مشــاهده مىشــود كه تفاوت معنادارى ميان

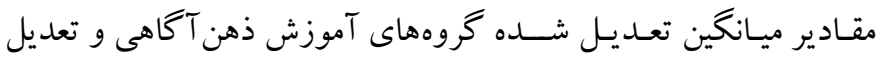

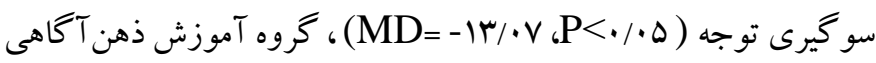

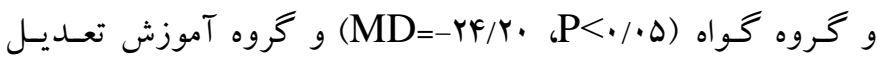

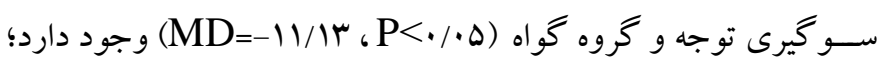
اين يافته بدان معناسـت كه هر دو روش آموزش مبتنى بر ذهن آكاهى و وهوه

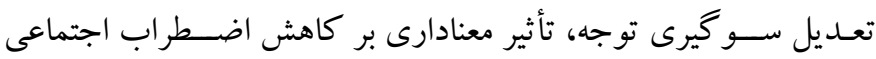

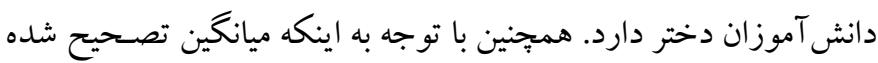

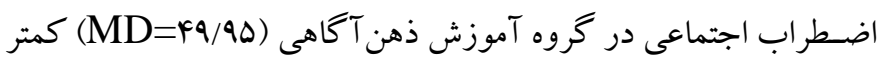

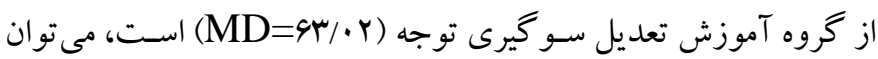

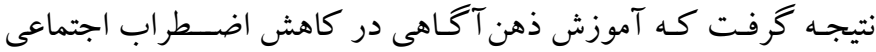
دانش آموزان مؤثرتر بوده است.

\section{بحث و نتيجه كيرى}

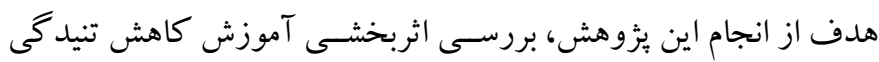

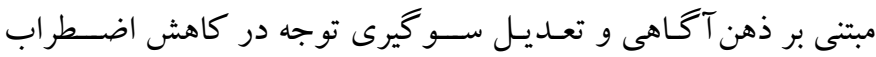
اجتماعى و همجنين مقايسه اثربخشى اين دو آموزش بر كاهش اضطراب

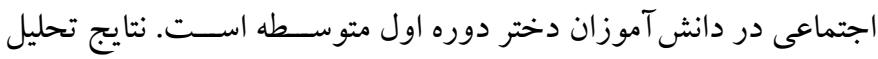
كواريـانس تككمتغرى يكراهه و آزمون تعقيبى بونفرونى نشــان داد كه دوره

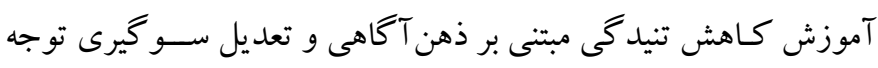

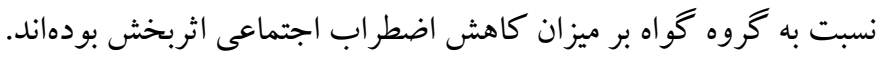

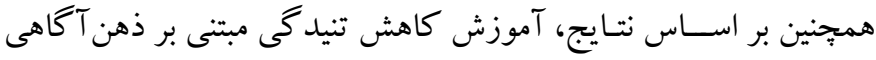

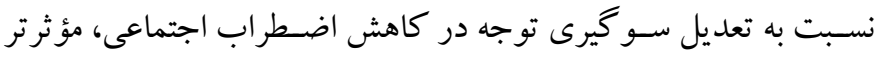

$$
\text { بوده است. }
$$

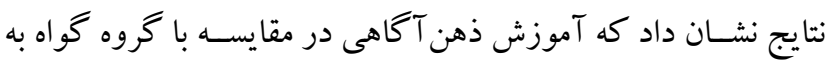

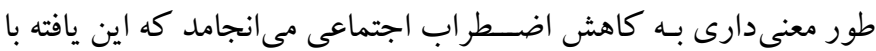

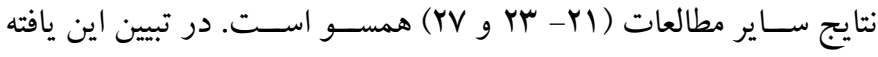
مى توان كفـت كه ذهن آكاهى به افراد كمكك مى كند تا موقعيت هايى را

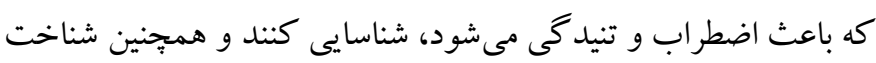
بهترى نسـبت به خود بيدا كرده و نقاط قوت و ضعف خوس خود را بشناسد و ســس راهبردهـاى مقـابلهاى براى مواجهه با اين موقعيتها را بياموزند.

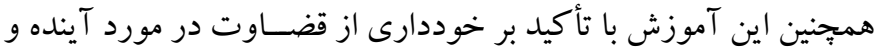


تجربيات خود به شـركت كنند گان ارائه دهد. اين شـيوه درمان به كاهش هزينه درمانى منجر شــده و هدف آن به طور خاص، بهبود تنظيم هيجان،

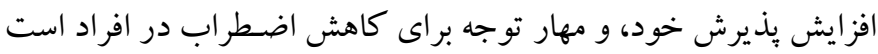

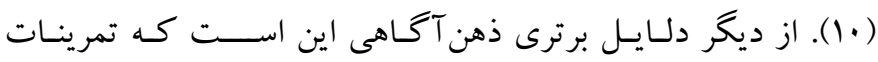

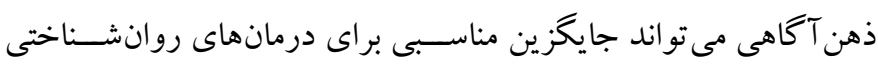

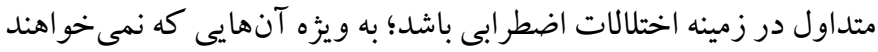
در جلسـات درمانهاى سـنتى شـر كت كنند و يا اشـخاصى كه به درمان،

$$
\text { باسخ نمى دهند (به نقل ازها) }
$$

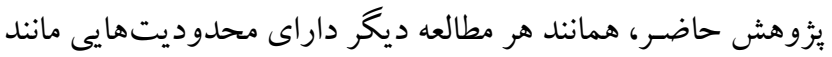
محدود بودن نتايج بزوهش به دوره تحصيلى و سن افراد نمونه است كه در صورت تغيير نمونه و موقعيت يزوهش، امكان تغيير نتايج وجود دارد.

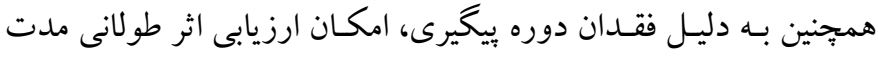

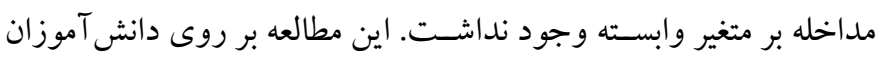

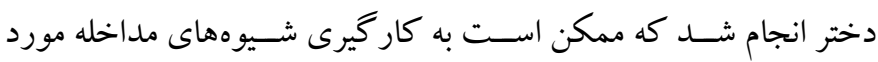
استفاده در اين يُزوهش، روى دانش آموزان يسر نتايج كاملاً متفاوتى را به به

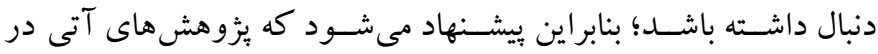

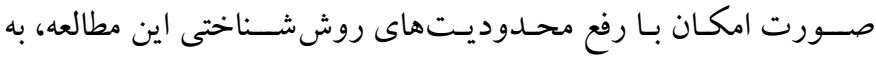
تعميمدهى نتايج به دست آمده، كمك كنند.

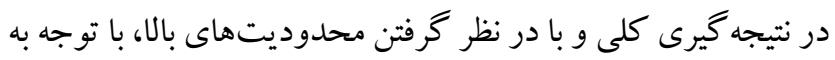

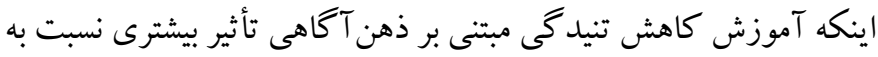

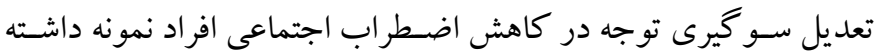

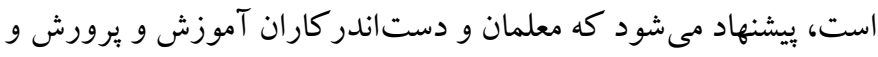

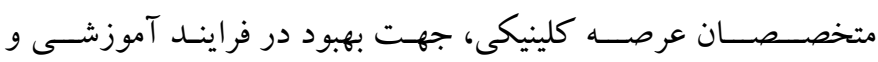

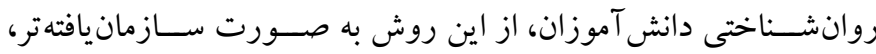

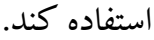
تشـكر و قدردانى: اين برُوهش بر خرفته از بايان نامه كارشـناسى ارشد خانم

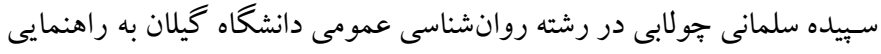

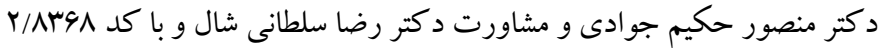
اسـت. همجينين مجوز اجراى اين مطالعه از سـوى آموزشو برورش شـهرســان

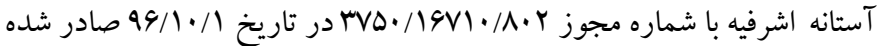
است. بدين وسيله از تمامى افرادى كه در اين مطالعه مشاركت داشتهاند، تشكر

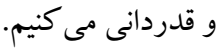
تضاد منافع: اين بثزوهش براى نويسند كان هيج كونه تضاد منافعى نداشته است.
تهـديـدكنــدهاى از اطلـاعـات عـادى دارند كه در نتيجه آموزش تعديل

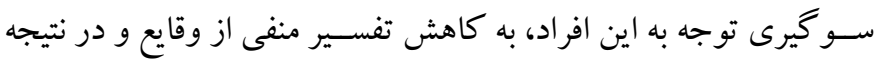

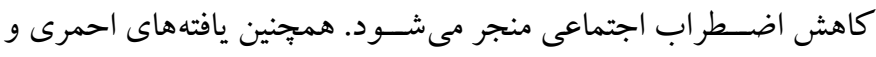

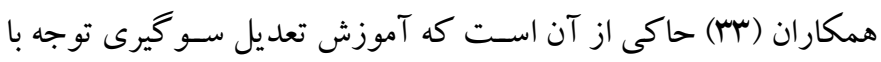

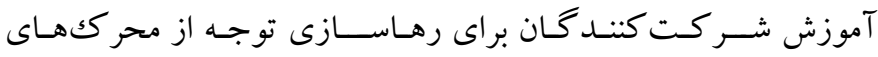
تهـديـدكنــده و توجـه به محرككهاى خنثى، مهارت بازدارى را در آنها

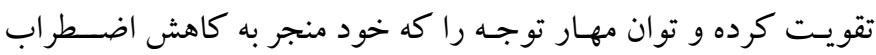

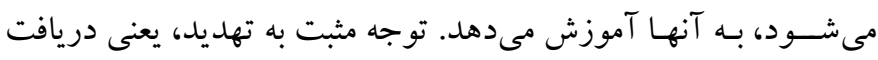

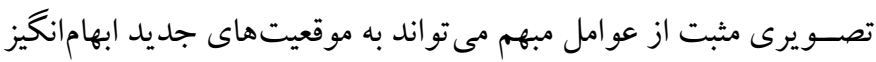
انتقال يافته و در نتيجه به تغيير در واكنش به رويداد هيجانى جديد، منجر

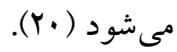

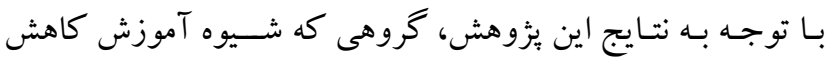

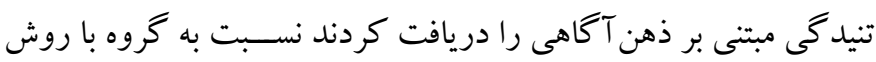
تعديل سو گيرى توجه، كاهش بيشترى در اضطر اب اجتماعى نشان دادند.

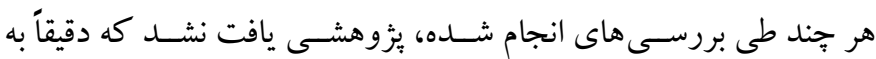

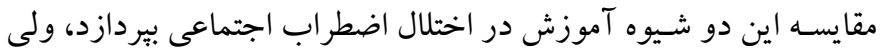
يززوهشهـاى مختلف كـار آمـدى آموزش ذهن آكَاهى را در كـاهش

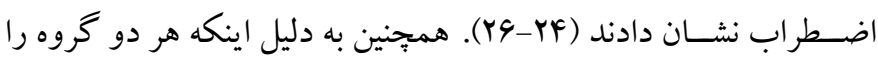

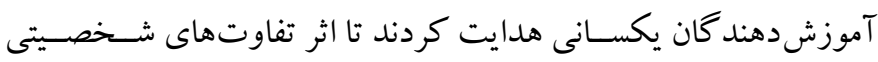

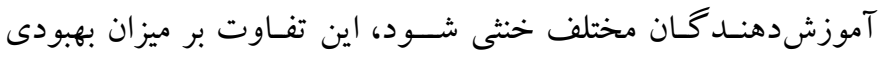

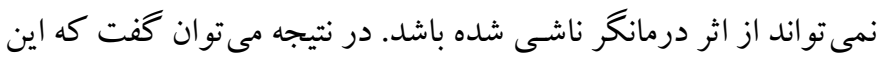

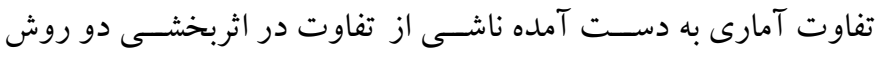

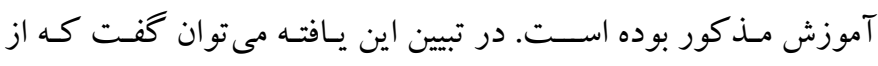

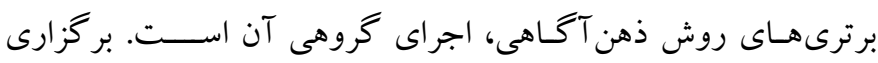

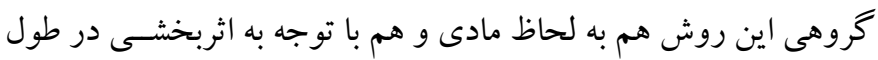
زمان، بيشتر از روشهاى فردى، مقرون به صـرفه است. علاوه بر اين، در

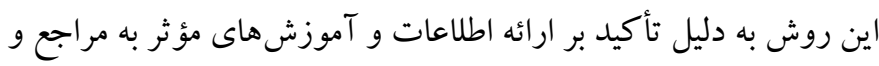

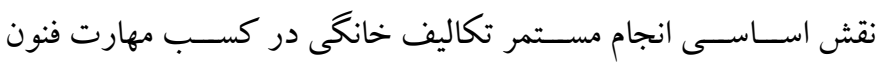

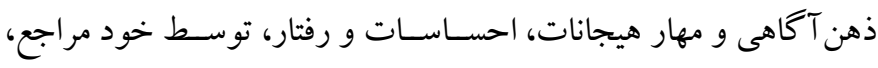
احتمال عود مشـكل را در دراز مدت كمتر مى كند. در مقايسـه با سـاير

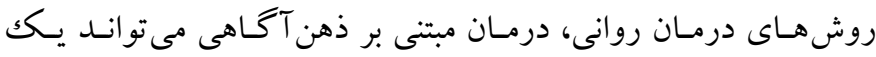

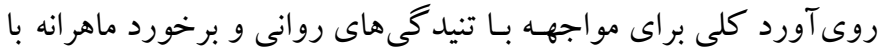




\section{References}

1. van Niekerk RE, Klein AM, Allart-van Dam E, Hudson JL, Rinck M, Hutschemaekers GJM, et al. The role of cognitive factors in childhood social anxiety: Social threat thoughts and social skills perception. Cogn Ther Res. 2017; 41(3): 489-497. [Link]

2. Dryman MT, Gardner S, Weeks JW, Heimberg RG. Social anxiety disorder and quality of life: How fears of negative and positive evaluation relate to specific domains of life satisfaction. J Anxiety Disord. 2016; 38: 1-8. [Link]

3. Mohapatra S, Agarwal V, Sitholey P. Pediatric anxiety disorders. Asian J Psychiatr. 2013; 6(5): 356-363. [Link]

4. Sackl-Pammer P, Jahn R, Özlü-Erkilic Z, Pollak E, Ohmann S, Schwarzenberg J, et al. Social anxiety disorder and emotion regulation problems in adolescents. Child Adolesc Psychiatry Ment Health. 2019; 13(1): 37. [Link]

5. Tassin C, Reynaert C, Jacques D, Zdanowicz N. Anxiety disorders in adolescence. Psychiatr Danub. 2014; 26(1): 27-30. [Link]

6. de Lijster JM, Dieleman GC, Utens EMWJ, Dierckx B, Wierenga M, Verhulst FC, et al. Social and academic functioning in adolescents with anxiety disorders: A systematic review. J Affect Disord. 2018; 230: 108117. [Link]

7. Zarafshan H, Mohammadi M-R, Salmanian M. Prevalence of anxiety disorders among children and adolescents in Iran: A systematic review. Iran $\mathbf{J}$ Psychiatry. 2015; 10(1): 1-7. [Persian]. [Link]

8. Bockstaele BV, Bögels SM. Chapter 25 - mindfulnessbased therapy for social anxiety disorder. In: Hofmann SG, DiBartolo PM, editors. Social anxiety (Third Edition). San Diego: Academic Press; 2014, pp: 729751. [Link]

9. Goldin PR, Gross JJ. Effects of mindfulness-based stress reduction (MBSR) on emotion regulation in social anxiety disorder. Emotion. 2010; 10(1): 83-91. [Link]

10. Piet J, Wurtzen H, Zachariae R. The effect of mindfulness-based therapy on symptoms of anxiety and depression in adult cancer patients and survivors: A systematic review and meta-analysis. J Consult Clin Psychol. 2012; 80(6): 1007-1020. [Link]

11. Bullis JR, Bøe HJ, Asnaani A, Hofmann SG. The benefits of being mindful: Trait mindfulness predicts less stress reactivity to suppression. J Behav Ther Exp Psychiatry. 2014; 45(1): 57-66. [Link]
12. Shabani J, Masdari M. The effectiveness of training mindfulness-based cognitive therapy on social anxiety disorder among first high school female students. Shenakht Journal of Psychology \& Psychiatry. 2016; 3(3): 12-27. [Persian]. [Link]

13. Brady VP, Whitman SM. An acceptance and mindfulness-based approach to social phobia: A case study. J Coll Couns. 2012; 15(1): 81-96. [Link]

14. Semple RJ, Reid EFG, Miller L. Treating anxiety with mindfulness: An open trial of mindfulness training for anxious children. J Cogn Psychother. 2005; 19(4): 379-392. [Link]

15. Sheykholeslami A, Seyedesmaili Ghomi N. Comparing the effect of mindfulness-based stress reduction program and study skills training on the test anxiety in students. Journal of School Psychology. 2014; 3(2): 104-121. [Persian]. [Link]

16. Koster EHW, Fox E, MacLeod C. Introduction to the special section on cognitive bias modification in emotional disorders. J Abnorm Psychol. 2009; 118(1): 1-4. [Link]

17. Bantin T, Stevens S, Gerlach AL, Hermann C. What does the facial dot-probe task tell us about attentional processes in social anxiety? A systematic review. J Behav Ther Exp Psychiatry. 2016; 50: 40-51. [Link]

18. MacLeod C, Clarke PJF. The attentional bias modification approach to anxiety intervention. Clin Psychol Sci. 2015; 3(1): 58-78. [Link]

19. Salemink E, Kindt M, Rienties H, van den Hout M. Internet-based cognitive bias modification of interpretations in patients with anxiety disorders: A randomized controlled trial. J Behav Ther Exp Psychiatry. 2014; 45(1): 186-195. [Link]

20. Hertel PT, Mathews A. Cognitive bias modification: Past perspectives, current findings, and future applications. Perspect Psychol Sci. 2011; 6(6): 521536. [Link]

21. Ye H. Impact of mindfulness-based stress reduction (MBSR) on students' social anxiety: a randomized controlled trial. Neuroquantology. 2017; 15(4): 101106. [Link]

22. Mayorga MG, De Vries S, Wardle EA. Mindfulness behavior and its effects on anxiety. J Educ Psychol. 2016; 9(4): 1-7. [Link]

23. Hofmann SG, Sawyer AT, Witt AA, Oh D. The effect of mindfulness-based therapy on anxiety and depression: A meta-analytic review. J Consult Clin Psychol. 2010; 78(2): 169-183. [Link]

24. Zohrabi S, Shairi MR, Heydarinasab L. The effect of mindfulness and acceptance-based group therapy on decreasing fear of negative evaluation in patients with 
social anxiety disorder. Razi Journal of Medical Sciences. 2016; 22(140): 1-11. [Persian]. [Link]

25. Dehestani M. The effectiveness of mindfulness-based stress reduction program on depression, anxiety and depression of female students. Journal of Clinical Psychology Andishe va Rafter. 2015; 10(37): 47-56. [Persian]. [Link]

26. Razian S, Heydari Nasab L, Shairi MR, Zahrabi S. To investigate the effectiveness of mindfulness-based stress reduction program (MBSR) on reducing the symptoms of patients with social anxiety. Scientific Journal of Clinical Psychology \& Personality. 2015; 2(12): 37-50. [Persian]. [Link]

27. Moradi E. The effectiveness of cognitive-based mindfulness therapy on social anxiety in mothers with mentally educational knowledge. Rooyesh-eRavanshenasi Journal (RRJ). 2019; 8(6): 1-8. [Persian]. [Link]

28. Lowther H, Newman E. Attention bias modification $(\mathrm{ABM})$ as a treatment for child and adolescent anxiety: A systematic review. J Affect Disord. 2014; 168: 125-135. [Link]

29. De Voogd EL, Wiers RW, Prins PJM, Salemink E. Visual search attentional bias modification reduced social phobia in adolescents. J Behav Ther Exp Psychiatry. 2014; 45(2): 252-259. [Link]

30. Shafiei $H$, Zare $H$. Effectiveness of attention bias modification by computerized attention training on reducing social anxiety of adolescents. Advances in Cognitive Science. 2019; 21(2): 108-120. [Persian]. [Link]

31. Bechor M, Pettit JW, Silverman WK, Bar-Haim Y, Abend R, Pine DS, et al. Attention bias modification treatment for children with anxiety disorders who do not respond to cognitive behavioral therapy: A case series. J Anxiety Disord. 2014; 28(2): 154-159. [Link]

32. Reuland MM, Teachman BA. Interpretation bias modification for youth and their parents: A novel treatment for early adolescent social anxiety. J Anxiety Disord. 2014; 28(8): 851-864. [Link]

33. Ahmari M, Salehi Fadardi J, Amin Yazdi SA, Saber H. Effects of a modern cognitive bias modification program on attentional biases and social anxiety symptoms in socially-anxious students. Journal of Fundamentals of Mental Health. 2016; 18(1): 35-41. [Persian]. [Link]

34. Masia-Warner C, Storch EA, Pincus DB, Klein RG, Heimberg RG, Liebowitz MR. The liebowitz social anxiety scale for children and adolescents: An initial psychometric investigation. J Am Acad Child Adolesc Psychiatry. 2003; 42(9): 1076-1084. [Link]
35. Olivares J, Sánchez-García R, López-Pina JA. The Leibowitz social anxiety scale for children and adolescents. Psicothema. 2009; 21(3): 486-491. [Link]

36. Bahrami $M$, Abolghasemi A, Narimani $M$. Comparing of self-perception and safety measures in students with social anxiety disorder symptoms and normal students. Journal of School Psychology. 2012; 2(1): 62-79. [Persian]. [Link]

37. Ziaee SS, Zarrani F, Motabi F, Kareshki H, Shahidi S. Psychometric properties of post event processing questionnaire in student population. Quarterly of Educational Measurement. 2015; 6(22): 135-163. [Persian]. [Link]

38. Shafiee H, Zare H, Alipor A. Construction and validation of computer program of attention bias modification treatment for social anxiety disorder. Advances in Cognitive Science. 2017; 19(2): 19-29. [Persian]. [Link]

39. Dalir M, Alipour A, Zare H, Farzad V. The effect of cognitive bias modification therapy on symptoms of obsessive-compulsive disorder: Comparison efficacy of cognitive bias modification therapy and group cognitive-behavioral therapy. Clinical Psychology Studies. 2016; 6(21): 1-25. [Persian]. [Link]

40. Razmzan Z, Mohammadi N. Effectiveness of cognitive bias modification on social anxiety symptoms and fear of negative evaluation. Journal of Psychology. 2016; 20(1): 57-74. [Persian]. [Link]

41. Pishyar R, Harris LM, Menzies RG. Attentional bias for words and faces in social anxiety. Anxiety Stress Coping. 2004; 17(1): 23-36. [Link]

42. Kabat-Zinn J, Massion AO, Kristeller J, Peterson LG, Fletcher KE, Pbert L, Lenderking WR, Santorelli SF. Effectiveness of a meditation-based stress reduction program in the treatment of anxiety disorders. Am J Psychiatry. 1992; 149(7): 936-943. [Link]

43. Ghamari M, Hosseini G. The effectiveness of mindfulness-based stress reduction training program on female students, test anxiety. Journal of Woman and Culture. 2017; 9(31): 33-43. [Persian]. [Link]

44. Arab Ghaeni M, Hashemian K, Mojtabaei M, Majd Ara E, Aghabeiki A. The effect of mindfulness training (MBSR) on the increasing assertiveness among anxious students. Studies in Medical Sciences. 2017; 28(2): 119-129. [Persian]. [Link]

45. Orchard F, Apetroaia A, Clarke K, Creswell C. Cognitive bias modification of interpretation in children with social anxiety disorder. J Anxiety Disord. 2017; 45: 1-8. [Link] 